\title{
NEW QUALITY OF LIFE IN A CONSUMER SOCIETY, GEORGE RITZER, BENJAMIN BARBER AND THE MAGICAL WORLD OF CONSUMPTION
}

\begin{abstract}
The consumer society is a society full of goods. A consumer is a man surrounded by objects, and the amount of goods used by consumer testifies his place in the society. A big consumption is better than the lower one. The level of consumption speaks about the status of consumer. In a consumer society everything is focused on the material values. This is true also for the quality of life.

The quality of life is difficult to define, it is a highly subjective issue. The quality of life of a consumer is determined by the principles and rules of the world of consumption. The more expensive are one's holidays, the more exotic place one is heading for, the more it is valuable and precious. It does not matter what is giving one a real rest, it matters only what is trendy, compatible with the current fashion which changes every season. It does not allow the consumer to be stuck in a root, to a certain degree of stagnation and satisfaction. $\mathrm{He}$ should incessantly strive to the realization of the current standards, set by what is fashionable and advertised (at the very moment). Georg Ritzer and Benjamin Barber are showing how the new understanding of what is the quality of life and how it is changing the consumer's life. A consumer is submitted to the dictatorship of those who are setting the trends. The submission is voluntary. A human - consumer wants to be similar to the other peoples and to feel good in the society to which one belongs. The rejection of the principles and the rules of the world of consumption could make him being regarded as nonfashionable and in result as non-significant at all. The quality of life of a consumer who does not want to meet the demands of the world of consumption, is perceived as very low, and as a result such a person is not valued as a neighbour, nor as an employee.
\end{abstract}

Keywords: consumer society, quality of life, world of consumption

As we used to say, the philosophical category of quality of life is a degree of excellence. The quality of life is also defined as a degree of satisfaction with life in the long term. It is difficult to measure the quality of life. If a measure of the quality of life is a degree of satisfaction with life, each person will use a different criterion for assessing their quality of life.

The modern consumer society is in many ways different from earlier ones.It has developed on a basis of a democratic state society due to possibilities offered by democratic order. Differences between a consumer society and a democratic society appear at different levels of socio-political life. Additionally, the criteria of assessing a degree of success in lifeand thus leading life of an appropriate quality are different in the consumer society and in the democratic society.

\footnotetext{
${ }^{1}$ Dr hab. Joanna Mysona Byrska, Uniwersytet Papieski Jana Pawła II w Krakowie, Katedra Filozofii Społecznej i Polityki, ul. Bernardyńska 3, e-mail: joanna.mysona.byrska@upjp2.edu.pl
} 
The consumer society and the whole world of consumption are focused on material values which provide an access to the immensity of available goods and lead to hyperconsumption ${ }^{2}$ by using the new media of consumption.

George Ritzer and Benjamin Barber in their work on the state of modern societies show a consumer societywhich is globalized and McDonalized, which means that consumers behavior is systematically aligned ${ }^{3}$.

Along with these changes, it seems that there is also a new quality of life, which is not determined by an individual person but by the logic of the world of consumption. To identify the criteria for assessing the quality of life in the world of consumption, it is essential to ask about the most characteristic features of this world. Secondly, we have to think about what a proper measure of the quality of life is for an average consumer today and which aspects have lost their meaning.

\section{THE MAGIC WORLD FULL OF GOODS}

The world of consumption is called magic by George Ritzer, which is a direct reference to the terminology used by Max Weber. The magic world of consumerism is based primarily on the creative power of this world and the emergence of consumption places, which have "a quasi-religious, magical character"4. In this world the reality will be magical, and a normal shopping takes on the character of a religious pilgrimage because ofan almost supernaturalaspectofthe "temples of consumption". Shopping malls seem to have replacedchurches and other religious places in the world of consumption and have become "temples of consumption"5. In place of the real world there enters a simulation of the world; true reality is imitated and copied, which can deprive it of any so-called "uninteresting" traits. This imitated reality has become the standard reality. Thanks to this process, the world becomes colorful, beautiful, predictable and safe $^{6}$. In this world the most important place is a shopping mall - "the temple of consumption"7. A comparison between a shopping mall or a department store to the temple stems from a simple fact: they are usually open on Sundays and attract people hard, sometimes harder than cathedrals and churches ${ }^{8}$.

The world of magical consumption depends on the level of consumption; the higher consumption is, the better it is going on in this world, because profits rise.

The result is that "more" starts to mean "better". We may get an impression that in a while by a dialectical leap, the quantity will generate a new quality. The references to the philosophy of Karl Marx come automatically to mind, due to the terminology used -

${ }^{2}$ See: G. Ritzer, Magiczny świat konsumpcji, przeł. L. Stawowy, wyd. Muza SA, Warszawa 2009, p. 8.

${ }^{3}$ Benjamin Barber points out that it is not important in which country we live. A normal day of an average teenager looks everywhere the same:s/he dresses in Lewis jeans, takes a backpack and goes to school. Similarly, in case of an adult -a statistical person leaves the house in the morning andgoes to work. S/he returns after completing their duties in the evening.See: B. Barber, Skonsumowani. Jak rynek psuje dzieci, infantylizuje dorostych i potyka obywateli, przeł. H. Jankowska, wyd. Muza SA, Warszawa 2008, p. 29.

${ }^{4}$ G. Ritzer, op. cit., p. 8.

${ }^{5}$ Ibidem, s. 8, p. 23 and next.

${ }^{6}$ G. Ritzer, op. cit., p. $181-212$.

${ }^{7}$ Ibidem, p. 23.

${ }^{8}$ Ibidem. 
on purpose- both by Ritzer and Barber.It is said that in the magical world of consumption of "the new media of consumption"- which are "the places or structures that allow for a consumption of all sorts of things"9. Ritzer took the term of "new media of consumption" from Jean Baudrillard ${ }^{10}$, the postmodern social philosopher, who was in his early work influenced by the ideas of Karl Marx. The new media of consumption are not only goods and products, but according to Ritzer, they are also "a broader set of phenomena associated with the goods and services to which the production, advertising, marketing, sales, individual taste, style, and fashionbelong"11. In comparison, Jean Baudrillard addsmore elements of consumer society to new media of consumption: shopping malls, fast food, modern communication technology, drugstores, closed monitored modern housing estates, shopping and entertainment centers, university campuses (they are now like shopping malls - you can get everything you need and not just go to lectures and the library), media etc. ${ }^{12}$

The world of consumption is the world of excess, abundance and hyper-consumption. The consumption becomes a quasi-religion; the level of consumption and the type of goods consumed is the determinant of living standards. Benjamin Barber in his analysis of the world of consumption concludes that shopping appears to be a measure of freedom, thusnot, as in democratic societies, is participation in elections. The future of a person is determined by his/her activities in a shopping mall, and not - as it used to be in the past by his/her activities in the public space. An individual determines his/ her future through his/ her activities at the mall ${ }^{13}$.

Benjamin Barber in his diagnosis of the world of capitalism speaks of the "swallowed citizens". In place of the ethos of work andsaving, the ethos of infantilism appeared. According to Barber, the society was literally "consumed". By "consumed" he means the subordination of today's capitalism to consumption. The most important is consumption, not production, because the level of consumption today is responsible for progress and development ${ }^{14}$. What Barber means it that the consumption growth promotes the ethos of infantilism, and together with it there appears a new approach to the world.

\section{LIVING IN THE WORLD: "I WANT TO MAKE IT HAPPEN"}

The world of consumption is governed not only by the mentality of a miracle and not only by magical thinking ${ }^{15}$. In the magical world of consumption traditional life cycle stages disappear. People - if they wish so - can remain young forever. They do not have to grow up, which is associated with duties, restrictions and the postponement of gratification for the undertaken effort. Peter Pan is a common and desirable attitude in the society of consumption, because he is not responsible, he reacts spontaneously to all the temptations of consumption society.

\footnotetext{
${ }^{9}$ Ibidem, p. 21.

${ }^{10}$ See: Ibidem, p. 108 - 109.

${ }^{11}$ Ibidem, p. 21.

${ }^{12}$ See. J. Baudrillard, Społeczeństwo konsumpcyjne. Jego mity i struktury, przeł. S. Królak, ed. Sic!, Warszawa 2006, p. $75-100$.

${ }^{13}$ B. Barber, op. cit., p. 56.

14 Ibidem.

${ }^{15}$ J. Baudrillard, op. cit., p. 16.
} 
The logic of the world of consumption promotes the ethos of infantile. Maintaining childishness allows for an easier implementation of the imperative of capitalism: to sell ${ }^{16}$ ! Children want to buy everything, they don't have developed skills of needs'selection and they expect an immediate gratification. The world of consumption promotes infantilism. The aim of this promotion is: "(...) to immunize adult children's characteristics and behavior of these characteristics"17. Benjamin Barber cites a social critic Neil Postman who demonstrates the existence of a simple dualism of child / adult. For the world of consumption, children are better consumers than adults because a child chooses: "pulse in place of prudence, feeling over reason, certainty over uncertainty, dogmatism in place of doubt, play over work, images over words, imagination over important ideas, pleasure over happiness, instant gratification over long-term satisfaction, selfishness over altruism, private over public, in place of socialization of narcissism, the permission (right) of the obligation (responsibility), the eternal present of the sense of time (now over past and future), close to the far (immediate over assets), the natural love in place of erotic sexuality, individuality over community, ignorance over knowledge" 18 .

The adults who are still children are easily persuaded to consume. Following theinfantilisation, there appears a promotion of "egocentric personal choices and of narcissistic personal benefits"19. When adult people behave like spoiled children, the world of consumption considers it as having real power and being a truly free person. The problem is that this is an authority, which means the absolutization of personal freedom and the absence of any consequences. Decisions of adult children, according to the ethos of the infantile, should not have any consequences nor unpleasant effects ${ }^{20}$. With this approach, people can consume more, much more. Modern banking products, which enable immediate purchase of a desired product on credit, allow for an increase in normal consumption. A postponed payment does not appear to be excessive. According to the dependence of the world of consumption on a steady increase in consumption, everything which is conducive to such growth is promoted as desirable and as improving the quality of life. As Ritzer finds, what is interesting is the exchange process, a constant rotation of $\operatorname{goods}^{21}$.

\section{THE CRITERIA FOR THE QUALITY OF LIFE IN THE WORLD OF CONSUMPTION}

The quality of life in the world of consumption is determined by the level of consumption. The consumption of more goods reflects a better quality of life. It appears that there is a rule: "Tell me what you put in the trash, and I'll tell you who you are!"22. Garbage and junk determine what the quality of your life is. According to the logic of the world of consumption, the more valuable things are wasted, the higher the standard of living and its quality. They are followed, in accordance with the logic of consumption,by

\footnotetext{
${ }^{16}$ B. Barber, op. cit., p. 15.

${ }^{17}$ Ibidem, p. 130.

${ }^{18}$ Ibidem, p. 131

${ }^{19}$ Ibidem, p. 27.

${ }^{20}$ Ibidem, p. 48.

${ }^{21}$ G. Ritzer, op. cit., p. 23.

22 J. Baudrillard, op. cit., p. 35.
} 
a sense of happiness and life success ${ }^{23}$. Good quality garbage indicates a high social status. Good quality garbage and a high level of consumption translate into the success in life. The level of subjective satisfaction with a low level of consumption appears to be at odds with the logic of the world of "the temples of consumption".

The new heroes of consumption society are celebrities, whose quality of life presented in the media world is the highest possible. Celebrities are the masters of waste, they are "the embodiment of luxury, purposeless and expanded spending on anything", which is how one should behave a role model in accordance with the logic of this world. ${ }^{24}$ According to the logic of the world of consumption, celebrities are role models. Celebrities show how to achieve success in the world of consumption and by what criteria it is measured. If the needs of people from the front pages of glossy magazines are your needs, it indicates a sufficiently high level and social status. For Jean Baudrillard these needs are artificially generated ${ }^{25}$. The implementation of these needs can significantly rise the social status. They are objectively verifiable criteria and reduced to the number of goods.In line with the ethos of infantilisation mentioned by Barber, the possibility of immediate implementation of the needs generated here and now is an important determinant of the quality of life. The ones who can realize their needs without having to wait, belong to the consumers of the appropriate level of consumption and the high quality of life. The consequences are not relevant and are not important.

The quality of life increases a degree of the lack of commitment, independence and need to be responsible for nothing. This is in compliance with the logic of the world of consumption $^{26}$. The transfer of the world of consumption is simple: stay a child, and then the quality of your life will be greater than the quality of life of an always worried adult ${ }^{27}$. Mindlessconsumptionpositivelyaffects the profit.

The quality of life in the world of consumption clearly defines the levels of consumption. More is better and there are no exceptions to this rule. A spiritual dimension is lost; the evaluation criteria are only external ones - objective and intersubjectively verifiable, in accordance with the tendency to subordinate everything to the standards. For example, the quality of holiday shows the following: the distance from home (the further the better, preferably in an exotic country), the amount of money spent (an expensive holiday is better quality than a cheap one), a degree of tan, the amount of the bought souvenirs and advertising (no color packaging and the value of a product decreases). The quality of the holidays indicates the agency where they were purchased and a place in the ranking of holiday offers. The level of satisfaction is also important, but can you be dissatisfied after the holiday on Bora Bora or in another exotic and trendy place? By definition, after a holiday in an exclusive place where celebrities rest, you have to be satisfied; the satisfaction was bought along with a place in the hotel. Suitable "mythical" processing around the idea of holidays raises their rank and the quality of life for vacationers. A hammock in your garden cannot be compared with a hammock in an exclusive place where you lie downjust like a Hollywood star.

\footnotetext{
${ }^{23}$ Ibidem, p. 35 and next.

${ }^{24}$ Ibidem, p. 41.

${ }^{25}$ Ibidem, p. $40-41$.

${ }^{26}$ B. Barber, op. cit., p. 47.

${ }^{27}$ Ibidem, p. $47-48$.
} 
It stems from the above, that in the society of consumption, which for Baudrillard smells like potlatch ${ }^{28}$, happiness and the quality of life with it, does not depend on subjective feelings, but it is generated accordingly to the degree of consumption and possession. When you don't have relevant goods, you can't consume them at an adequate level and you're not happy;you can't be happybecause your quality of life is too low. This characteristics appears in the work of Jean Baudrillard and George Ritzer. They describe the magical world of consumption. We can find the same by Benjamin Barber. New benchmarks of the quality of life in a consumer society are tangible and financial resources.A spiritual dimension of the quality of life in a consumer society is lost; it is not measurable and does not generate measurable gains. There is spreading blindness when political and community dimensions are concerned. According to Barber, this threatens modern consumer societies, because at their core they are based on the democratic order requiring the involvement of citizens ${ }^{29}$.

\section{ADVERTISING AND ITS CRITERIA FOR THE QUALITY OF LIFE}

One of the tools to persuade people to consume is advertising. The world created by advertising is made up of brands and products to be acquired, and it suggests the existence of a "total population of consumers" 30 . Buying advertised products allows the buyer to feel as a part of this beautiful world.

The main task of any kind of advertising is to increase consumption. One type of ads refers to a subjective sense of the quality of life. This appears in spots such as "better people are drinking Pepsi".A hidden suggestion is that non-drinkers are recognized as the worse. If the recipient wants to belong to the colorful world, purchasing of Pepsi will enable him/ her to do so. The same effect is in the well-known advertising of Media Markt. The slogan is: "not for idiots". If the recipient doesn't want to be considered as an idiot, s/he should buy at Media Markt, and so s/he proves his/her intelligence. Recently, on Polish television in a commercialadvertising Activia (a yogurt which prevents digestive problems), we hear: "get free with Activia". Without a regular consumption of Activia, a woman is enslaved and cannot do what she wants and what her friends do, the friends who useActivia. If a woman wants to be free - to rise her quality of life - she should quickly buy Activia. Another commercialis a commercial for Snickers bar with the line: "if you are hungry you're not yourself". Only the consumption of a chocolate bar full of peanuts can restore a hungry person to "being themselves".

Also the IKEA network calls for improving the quality of life for their customers. We can find advertising spots encouragingbuying like: "personalize your house",or "you arrange you house because you govern here". If the customer lacks IKEA products in his/her household, his/ her house will not be personalized, so the quality of his/ her life will be lower, because of the lack of furniture from IKEA and it will not betruly his/ her home.

\footnotetext{
${ }^{28}$ This is the ritual ceremony of indigenous people around Vancouver. Potlatch is celebrated wastage, destruction and disposing of goods specially prepared for this occasion. Amount of goods consumed during potlatch indicates personal social status. Regarding potlatch see: http://wigwam02.republika.pl/Wigwam28/pliki/potlacz5.html, 07.06.2011.

${ }^{29}$ B. Barber, op. cit., p. 56.

${ }^{30}$ J. Baudrillard, op. cit., p. 162.
} 
According to the incentives provided by advertisements, a man should "improve" himself, and then he becomes more himself and the quality of his life will be better. It seems that an adequate consumption makes them more human. One can get an impression that with an appropriate level of consumption, an individualbecomes a different, better person, who is a better human than before. And from this experience, there is only one step to the diagnosis ofJean Baudrillard and the recognition that the consumption society is ruled by ideas analogous to the communist society.

The consumption humanizes the people in the consumption society, in the communist society the people were humanized by the work. George Ritzer also points out some analogies in the world of consumption to the twentieth-century capitalism. In the world of capitalism a laborer was subjected to exploitation; in a world of consumption, in which consumption is much important than production, the consumer has become the object of a new control and a new exploitation ${ }^{31}$. The new exploitation is based on a consumer's susceptibility to incitement to consume beyond measure and over the possibility of financial resources and consumption ${ }^{32}$.

The quality of life in the world of consumption is measured primarily by tangible quantitative criteria. More means better, higher consumption -a better quality of life. Intangible values withdrawinto the background, and the measure of success in life is owned to tangible property. Consumed products and services are wrapped in emotions, promises and hopes;consumption is not a simple wear and tear item. Often by the means of consumption, the consumer wishes to join the ranks of thechosen ones, whose quality of life (the level of satisfaction and the social status) she or he is trying to achieve.

\section{REFERENCES}

[1] Barber B., Skonsumowani. Jak rynek psuje dzieci, infantylizuje dorostych $i$ potyka obywateli, ed. Muza SA, Warszawa 2008.

[2] Baudrillard J., Spoteczeństwo konsumpcyjne. Jego mity i struktury, ed. Sic!, Warszawa 2006.

[3] Ritzer G., Magiczny świat konsumpcji, ed. Muza SA, Warszawa 2009.

[4] http://wigwam02.republika.pl/Wigwam28/pliki/potlacz5.html, 07.06.2011.

\section{NOWA JAKOŚĆ ŻYCIA SPOŁECZEŃSTWA KONSUMPCYJNEGO. GEORG RITZER, BENJAMIN BARBER I MAGICZNY ŚWIAT KONSUMPCJI}

Społeczeństwo konsumpcyjne to społeczeństwo pełne dóbr. Konsument jest człowiekiem otoczonym przez przedmioty, a poziom ilość użytkowanych przez konsumenta dóbr, świadczy o zajmowanym przez niego w społeczeństwie miejscu. Im większa konsumpcja, tym lepsza jakość życia konsumenta. W społeczeństwie konsumpcyjnym życie skupia się na wartościach materialnych, zatem również o jakości życia świadczy jedynie ilość posiadanych dóbr materialnych. Jakość życia trudno jest zdefiniować, jest to mocno subiektywny problem. Jakość życia konsumenta wyznaczana jest przez zasady i reguły świata konsumpcji. Im droższy urlop, im bardziej egzotyczne miejsce jako cel podróży, tym jest to bardziej wartościowe i cenione. Nie liczy się to, co daje rzeczywisty odpoczynek, liczy się to, co jest zgodne z aktualnie panującą modą, która co sezon się zmienia. Nie pozwala to konsumentowi na popadanie $\mathrm{w}$ rutynę, na pewną stagnację $\mathrm{i}$ zadowolenie.

\footnotetext{
${ }^{31}$ G. Ritzer, op. cit., p. 111.

${ }^{32}$ Ibidem, p. 111, compare: J. Baudrillard, op. cit., p. 101.
} 
Nieprzerwanie ma dążyć do realizacji aktualnych standardów, które są wyznaczane przez to, co modne i reklamowane. Georg Ritzer i Benjamin Barber pokazują jak nowe rozumienie czym jest jakość życia zmienia życie konsumenta. Konsument staje się podporządkowany dyktatowi tych, którzy wyznaczają trendy. Podporządkowanie jest dobrowolne. Człowiek konsument chce być taki jak inni ludzie i dobrze się czuć w społeczeństwie, do którego przynależy. Odrzucanie zasad i reguł świata konsumpcji może spowodować, że zostanie uznany za niemodnego i w efekcie za nic nieznaczącego. Jakość życia konsumenta, który nie chce spełniać wymagań świata konsumpcji, jest uznawana za bardzo niską, a w efekcie nie jest ceniony ani jako sąsiad, ani jako pracownik.

Słowa kluczowe: społeczeństwo konsumpcyjne, jakość życia, świat konsumpcji.

DOI:10.7862/rz.2015.hss.35

Przesłano do redakcji: wrzesień 2015

Przyjęto do druku: październik 2015 